\section{Medisin er politikk}

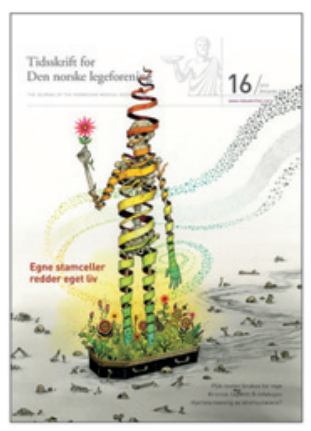

Selvsagt har Charlotte Haug rett i det hun fremfører i en leder i Tidsskriftet nr. 16/2013: at helse er politikk (1). Derfor er Helsetjenesteaksjonen (2) startet som en motvekt mot den helsepolitikken som de senere årene er ført med bred konsensus mellom regjeringspartier med ulik farge - $\mathrm{i}$ allianse med et raskt ekspanderende byråkrati uten kontakt med, eller legitimitet $\mathrm{i}$, helsetjenestens grunnplan. Men Haug argumenterer mot en parodi på Helsetjenesteaksjonens syn når hun skriver at vi vil gi fagmiljøene ubegrensede fullmakter til å bruke penger.

Tvert imot mener Helsetjenesteaksjonen at det er et politisk ansvar å bestemme helsetjenestens økonomiske rammer, herunder hvilke oppgaver som skal utføres, og hvilke som ikke skal utføres. Det er også politikerne som må bestemme om helseformål skal få en høyere, en lavere eller en uendret andel av landets samlede økonomiske ressurser. Disse avgjørelsene skal politikerne stå til ansvar for overfor sine velgere. Helsebudsjettet er ingen lukket boks uten prioriteringsflater mot andre samfunnsområder. Helsepersonell må yte motstand mot å få delegert prioriteringsoppgaver som i sin natur handler om politiske verdivalg. Helsefagene har derimot en viktig oppgave med å klargjøre hva som blir konsekvensene av ulike politiske handlinger. Det må vi gjøre på en nøktern måte uten å overselge effektene av de behandlingstiltakene vi kan tilby. På dette området har ikke medisinen alltid holdt sin sti ren.

Fra samfunnsfaglig hold er det de senere årene beskrevet hvordan byråkrat- og konsulentmakt ekspanderer, både på bekostning av politikernes overordnede prioriteringsansvar og på bekostning av fagmiljøenes autonomi i sitt daglige virke $(3,4)$. Dette har ikke bare rammet helsesektoren, men også eksempelvis skolene, universitetene og politiet. Konsernorganiseringen av sykehusene, som Haug med stor kraft og stor rett har kritisert (5), vedtaksomsorgen i kommunene og den forkvaklede bruken av markedstenkning der intet marked finnes, er alt sammen fasetter av den samme utviklingen.

Haug beskriver politikk som om det bare var snakk om å velge mellom to forhåndsbestemte blokker. Dette blir for snevert, særlig når de to blokkene har vært så enige om de viktige spørsmålene. Det er på tide at helsepersonell ikke lar seg målbinde til å diskutere bare noen få spørsmål som politikerne har valgt ut (som grad av privatisering), men selv engasjerer seg for å tvinge frem en langt bredere diskusjon om helsetjenestens fremtidige kurs.

Ja, medisin er i sannhet politikk!

\section{Torgeir Bruun Wyller}

t.b.wyller@medisin.uio.no

Torgeir Bruun Wyller (f. 1960) er professor ved Geriatrisk avdeling, Oslo universitetssykehus.

Oppgitte interessekonflikter: Forfatter er talsperson for Helsetjenesteaksjonen og en av initiativtakerne til aksjonen.

\footnotetext{
Litteratur

1. Haug C. Medisinen er ikke politisk nøytral. Tidsskr Nor Legeforen 2013; 133 1677

Helsetjenesteaksjonen. http://helsetjenesteaksjonen.no (8.10.2013)

3. Slagstad R. Helsefeltets strateger. Tidsskr Nor Legeforen 2012; 132: 1479-85.

$\emptyset$ sterud $\emptyset$. Selle P. Power and democracy in Norway: the transformation of

Norwegian politics. Scand Polit Stud 2006; 29: 25-46.

5. Haug C. Alt på ett kort. Tidsskr Nor Legeforen 2012; 132: 2033
}

\section{Ikke stor effekt av PSA-screening}

I sin leder i Tidsskriftet nr. 16/2013 (1) skriver Anders Angelsen: «Ut fra matematiske modeller er det estimert at PSA-screening bidrar med 45-70\% i den observerte reduksjonen i prostatakreftspesifikk død, men at $23-42 \%$ av tilfellene av PSA-oppdaget prostatakreft er overdiagnostisering.» I denne modellen forutsetter man at en positiv PSA-test fremskynder tid for en prostatakreftdiagnose (lead time) med 5-12 år (1). Vi har nylig studert «lead time» i samme datasett som dem, og vi fant at «lead time» var mellom 0 og 1 år (2). Hvis vi har rett, så er alle deres beregninger gale.

Hvis PSA-testing fremskynder diagnosen med 0-1 år, kan man ikke forvente stor effekt av PSA-screening på dødelighet. Dessuten bør man vurdere om korrelasjonen har en annen fortolkning enn tidlig diagnose, for eksempel kan lett forhøyet PSA-nivå skyldes en reaksjon på en liten kreftsvulst som spontant helbredes, og at man måler kroppens reaksjon på spontan regresjon. I så tilfelle er dette ikke tidlig diagnose, men for sen diagnose (diagnostikk av svulster som går over av seg selv).

Angelsen skriver videre: «I en oversiktsartikkel hvor effekten av systematisk informasjon om PSA-testens fordeler og ulemper ble undersøkt, fant man at kun $12 \%$ valgte bort testen etterpå.» Dette tallet avhenger av hvordan man spør, og hvordan man tolker svarene. I randomiserte studier av PSA-screening var det ikke slik at nesten alle ( $88 \%$ hvis man bruker Angelsens argument) krevde å bli testet (3-5). Nesten $100 \%$ (noen ville ikke være med på en randomisert studie) godtok at de med 50\% sannsynlighet ikke ble testet. Angelsen skriver også at $46 \%$ av dem med «lavrisiko prostatakreft» godtok ingen behandling. Dette tolker jeg som at menn flest er lite interessert i å bli testet (og heller ikke ønsker å bli unødvendig behandlet), men at leger frister menn til å teste seg ved å gi mangelfull informasjon. En grunn til at leger holder tilbake informasjon, er at de ønsker å beskytte seg selv mot påstander om at svulster er blitt oversett og diagnostisert for sent. Men dette er ingen akseptabel forklaring.

\section{Per-Henrik Zahl}

per-henrik.zahl@fhi.no

Per-Henrik Zahl (f. 1961) er lege og statistiker ved Nasjonalt folkehelseinstitutt.

Ingen oppgitte interessekonflikter.

Litteratur

1. Angelsen A. Overforbruk av PSA-test hos friske menn. Tidsskr Nor Legeforen 2013; 133: 1678.

2. Draisma G, Etzioni R, Tsodikov A et al. Lead time and overdiagnosis in prostate specific antigen screening: importance of methods and context. J Natl Cancer Inst 2009: 101: 374-83.

3. Zahl P-H, Jørgensen KJ, Gøtzsche PC. Overestimated lead times in cancer screening has led to substantial underestimation of overdiagnosis. Br J Cancer 2013; 109: 2014-9

4. Volk RJ, Hawley ST, Kneuper S et al. Trials of decision aids for prostate cancer screening: a systematic review. Am J Prev Med 2007: 33: 428-34, e11.

5. Godtman RA, Holmberg E, Khatami A et al. Outcome following active surveillance of men with screen-detected prostate cancer. Results from the Göteborg randomised population-based prostate cancer screening trial. Eur Urol 2013; 63: 101-7.

Dette er en redigert versjon av debatten, publisert som rask respons på nett 3.9.2013. http://tidsskriftet.no/article/3050318/ 